\title{
MEDIA USE AND PREFERENCE RELATED TO CORONARY HEART DISEASE OF THE COLOURED POPULATION OF THE CAPE PENINSULA THE CRISIC STUDY
}

\author{
M. Steyn, K. Steyn
}

\section{Summary}

As a part of a comprehensive coronary risk factor study among the coloured population of the Cape Peninsula (the CRISIC study), the media use and preference of the population were examined with a view to suggesting appropriate media for conveying health messages.

A stratified sample $(N=976)$ was randomly drawn from the coloured population in the age group 15 to 64 years in the Cape Peninsula. Data were collected by means of a pre-tested questionnaire. Analysis of the data showed that information on the prevention of heart disease was obtained in greater measure from the mass media than from interpersonal communication. As far as media preference is concerned, television was considered the most effective medium for conveying information to the community, followed by instruction given to school children.

Greater use of health educators to convey health messages, as well as a multi-media approach, is suggested for a suecessful intervention programme.

\section{Opsomming}

As deel van die omvattende koronêre risikofaktorstudie by die

kleurlingbevolking van die Kaapse Skiereiland (die KRISIK-studie), is ondersoek ingestel na die mediagebruik en-voorkeure van die bevolking met die oog daarop om geskikte media vir die oordrag van gesondheidsboodskappe aan die hand te doen.

in Gestratifiseerde steekproef $(N=$
976) is ewekansig getrek uit die kleurlingbevolking in die ouderdomsgroep 15 tot 64 jaar. Data is deur middel van ' $n$ voorafgetoetste vraelys ingesamel. Ontleding van die gegewens het getoon dat inligting oor die voorkoming van koronêre hartsiekte in ' $n$ groter mate verkry is uit die massamedia as deur middel van interpersoonlike kommunikasie. Wat mediavoorkeure betref, is die televisie, gevolg deur onderrig aan skoolkinders, as die doeltreffendste middel beskou om gesondheidsboodskappe aan die gemeenskap oor te dra.

'n Meer uitgebreide gebruik van gesondheidsvoorligters om gesondheidsboodskappe oor te dra, asook ' $n$ multimediabenadering word aan die hand gedoen vir 'n suksesvolle tussentrede-program.

\section{INTRODUCTION}

In previous reports of the coronary risk factor study among the coloured population of the Cape Peninsula (CRISIC study) it was shown that this population had a poor coronary heart disease (CHD) risk factor profile and that there was a great need for an effective CHD prevention programme (Steyn K. et al. 1985, 1986, 1987a, 1987b, 1989a, 1989b - accepted for publication). In order to develop an intervention programme for CHD, which will attempt to improve the population's knowledge and behaviour regarding $C H D$ a situation analysis is essential. Such an analysis should contain a disease profile, information on cultural and demographic matters, information on the knowledge, attitudes and beliefs concerning the disease entity, and on the use and preference in respect of communication media. As a part of the comprehensive CRISIC study in which the above factors were studied, the media use and preference of the population were examined with a view to suggesting media for conveying health messages.

\section{STUDY POPULATION AND} METHODS

By using a multi-staged probability sampling technique an age and sex stratified sample of 976 respondents was randomly drawn from 485120 coloured people in the age group 15 to 64 in the Cape Peninsula as reflected in the 5\% subsample of the 1980 census. In each household drawn, only one member was selected. Criteria for exclusion from the study were pregnancy, being bedridden, mental retardation, carcinoma, leg amputation, drug therapy to counter tuberculosis, hospitalisation for more than one week during the previous three months and an inability or unwillingness to participate. The realised sample is shown in Table 1.

Trained fieldworkers visited respondents in their homes. Data were collected by means of a pre-tested questionnaire. Two questions concerning media use and preference were asked: one on the media (sources) from which information about CHD prevention was obtained and the other on which media they considered to be the most effective in providing their community with information on the prevention of $\mathrm{CHD}$.

\section{RESULTS}

Sources of Information

The sources of information through which the respondents had learnt how to keep their hearts healthy are shown in Table 2 . Information was obtained in a greater measure from mass media (television, written material, radio and posters) than from interpersonal communication. Of the mass media television was mentioned most often (males $70 \%$, females $67 \%$ ), followed by reading matter (males $57 \%$, females $55 \%$ ) and the radio (males $41 \%$, females $40 \%$ ), and lastly posters displayed in public places (males $44 \%$, females $37 \%$ ). Although there were relatively small differences between the different age groups, it is interesting to note that the males as well as the females in the younger age group (15 to 24 years) mentioned written materials and posters more often than did those in the older age groups, whereas they mentioned the radio less often. 


\begin{tabular}{|c|c|c|c|c|c|c|}
\hline \multirow{3}{*}{ Respondents } & \multicolumn{5}{|c|}{$\begin{array}{c}\text { TABLE 1 } \\
\text { Sample distribution }\end{array}$} & \multirow[b]{3}{*}{ Total } \\
\hline & \multicolumn{5}{|c|}{ Age in years } & \\
\hline & $15-24$ & $25-34$ & $35-44$ & $45-54$ & $55-64$ & \\
\hline Male & 94 & 96 & 103 & 95 & 90 & 478 \\
\hline Female & 103 & 94 & 112 & 95 & 95 & 498 \\
\hline
\end{tabular}

\begin{tabular}{|c|c|c|c|c|c|c|c|}
\hline \multicolumn{8}{|c|}{$\begin{array}{l}\text { TABLE 2 } \\
\end{array}$} \\
\hline \multicolumn{8}{|c|}{ Sources of health information according to sex and age } \\
\hline \multirow{2}{*}{$\begin{array}{l}\text { Source of infor- } \\
\text { mation }\end{array}$} & \multicolumn{6}{|c|}{ \% of participants in each age group } & \multirow{2}{*}{$\begin{array}{l}\text { Age standard- } \\
\text { ised rate* } \\
15-64\end{array}$} \\
\hline & Respondents & $15-24$ & $25-34$ & $35-44$ & $45-54$ & $55-64$ & \\
\hline Television & $\begin{array}{l}\text { Male } \\
\text { Female }\end{array}$ & $\begin{array}{l}68.1 \\
68.9\end{array}$ & $\begin{array}{l}70,8 \\
60,6\end{array}$ & $\begin{array}{l}75,7 \\
68,8\end{array}$ & $\begin{array}{l}66,3 \\
75,5\end{array}$ & $\begin{array}{l}68,9 \\
67,4\end{array}$ & $\begin{array}{l}69,9 \\
67,4\end{array}$ \\
\hline $\begin{array}{l}\text { Written material: } \\
\text { magazines, pam- } \\
\text { phlets, books, } \\
\text { newspapers }\end{array}$ & $\begin{array}{l}\text { Male } \\
\text { Female }\end{array}$ & $\begin{array}{l}62,8 \\
59,2\end{array}$ & $\begin{array}{l}57,3 \\
56,4\end{array}$ & $\begin{array}{l}54,4 \\
56,4\end{array}$ & $\begin{array}{l}52,6 \\
51,1\end{array}$ & $\begin{array}{l}41,1 \\
35,8\end{array}$ & $\begin{array}{l}57,4 \\
55,3\end{array}$ \\
\hline Radio & $\begin{array}{l}\text { Male } \\
\text { Female }\end{array}$ & $\begin{array}{l}37,2 \\
34,0\end{array}$ & $\begin{array}{l}42,7 \\
42,6\end{array}$ & $\begin{array}{l}45,6 \\
42,9\end{array}$ & $\begin{array}{l}41,1 \\
48,9\end{array}$ & $\begin{array}{l}42,2 \\
41,1\end{array}$ & $\begin{array}{l}40,8 \\
39,9\end{array}$ \\
\hline $\begin{array}{l}\text { Posters in } \\
\text { public places }\end{array}$ & $\begin{array}{l}\text { Male } \\
\text { Female }\end{array}$ & $\begin{array}{l}50,0 \\
38,8\end{array}$ & $\begin{array}{l}37,5 \\
37,2\end{array}$ & $\begin{array}{l}51,5 \\
33,0\end{array}$ & $\begin{array}{l}31,6 \\
37,2\end{array}$ & $\begin{array}{l}30,0 \\
28,4\end{array}$ & $\begin{array}{l}43,6 \\
36,5\end{array}$ \\
\hline $\begin{array}{l}\text { Doctors or } \\
\text { nurses }\end{array}$ & $\begin{array}{l}\text { Male } \\
\text { Female }\end{array}$ & $\begin{array}{l}14.9 \\
22,3\end{array}$ & $\begin{array}{l}21.9 \\
22,3\end{array}$ & $\begin{array}{l}29,1 \\
20,5\end{array}$ & $\begin{array}{l}26,3 \\
34,0\end{array}$ & $\begin{array}{l}37,8 \\
36,8\end{array}$ & $\begin{array}{l}21,9 \\
24,4\end{array}$ \\
\hline Friends & $\begin{array}{l}\text { Male } \\
\text { Female }\end{array}$ & $\begin{array}{l}23,4 \\
25,2\end{array}$ & $\begin{array}{l}25,0 \\
22,3\end{array}$ & $\begin{array}{l}11,7 \\
22,3\end{array}$ & $\begin{array}{l}17,9 \\
16,0\end{array}$ & $\begin{array}{l}25,6 \\
20,0\end{array}$ & $\begin{array}{l}21,4 \\
22,5\end{array}$ \\
\hline $\begin{array}{l}\text { Day hospitals } \\
\text { or clinics }\end{array}$ & $\begin{array}{l}\text { Male } \\
\text { Female }\end{array}$ & $\begin{array}{l}14,9 \\
16,5\end{array}$ & $\begin{array}{l}10,4 \\
17,0\end{array}$ & $\begin{array}{r}9,7 \\
17,9\end{array}$ & $\begin{array}{l}16,9 \\
17,0\end{array}$ & $\begin{array}{l}22,2 \\
31,6\end{array}$ & $\begin{array}{l}13,6 \\
18,0\end{array}$ \\
\hline $\begin{array}{l}\text { Teachers at } \\
\text { school }\end{array}$ & $\begin{array}{l}\text { Male } \\
\text { Female }\end{array}$ & $\begin{array}{l}41,5 \\
37,9\end{array}$ & $\begin{array}{l}14,6 \\
10,6\end{array}$ & $\begin{array}{r}16,5 \\
8,0\end{array}$ & $\begin{array}{l}9.5 \\
8,5\end{array}$ & $\begin{array}{l}3,3 \\
2,1\end{array}$ & $\begin{array}{l}24,3 \\
19,8\end{array}$ \\
\hline Work & $\begin{array}{l}\text { Male } \\
\text { Female }\end{array}$ & $\begin{array}{l}16,0 \\
12,6\end{array}$ & $\begin{array}{l}18,8 \\
10,6\end{array}$ & $\begin{array}{l}20,4 \\
10,7\end{array}$ & $\begin{array}{l}11,6 \\
12,8\end{array}$ & $\begin{array}{l}5,6 \\
4,2\end{array}$ & $\begin{array}{l}16,2 \\
11,2\end{array}$ \\
\hline $\begin{array}{l}\text { Children at } \\
\text { school }\end{array}$ & $\begin{array}{l}\text { Male } \\
\text { Female }\end{array}$ & $\begin{array}{r}10,6 \\
7,8\end{array}$ & $\begin{array}{l}5,2 \\
5,3\end{array}$ & $\begin{array}{l}7,8 \\
5,4\end{array}$ & $\begin{array}{l}3,2 \\
6,4\end{array}$ & $\begin{array}{l}6,7 \\
5,3\end{array}$ & $\begin{array}{l}6.4 \\
5,6\end{array}$ \\
\hline
\end{tabular}

\begin{tabular}{|c|c|c|c|c|c|c|c|}
\hline \multicolumn{8}{|c|}{ TABLE 3: } \\
\hline \multirow[t]{2}{*}{$\begin{array}{l}\text { Source of infor- } \\
\text { mation }\end{array}$} & \multicolumn{6}{|c|}{ \% of participants in each age group } & $\begin{array}{l}\text { Age standard } \\
\text { ised rate*" }\end{array}$ \\
\hline & Respondents & $15-24$ & $25-34$ & $35-44$ & $45-54$ & $55-64$ & $15-64$ \\
\hline 1. None & $\begin{array}{l}\text { Male } \\
\text { Female }\end{array}$ & $\begin{array}{l}10,6 \\
16,5\end{array}$ & $\begin{array}{l}17,7 \\
21,3\end{array}$ & $\begin{array}{l}13,6 \\
15,2\end{array}$ & $\begin{array}{r}14,7 \\
8.5\end{array}$ & $\begin{array}{l}13,3 \\
15,8\end{array}$ & $\begin{array}{l}13,6 \\
16,5\end{array}$ \\
\hline $\begin{array}{l}\text { 2. Health personnel } \\
\text { only }\end{array}$ & $\begin{array}{l}\text { Male } \\
\text { Female }\end{array}$ & $\overline{1,0}$ & $\begin{array}{l}1,0 \\
2,1\end{array}$ & $\begin{array}{l}2,9 \\
0,9\end{array}$ & $\overline{3.2}$ & $\begin{array}{l}1,1 \\
3,2\end{array}$ & $\begin{array}{l}1,0 \\
1,7\end{array}$ \\
\hline 3. Mass media only & $\begin{array}{l}\text { Male } \\
\text { Female }\end{array}$ & $\begin{array}{l}30,9 \\
23,3\end{array}$ & $\begin{array}{l}33,3 \\
32,0\end{array}$ & $\begin{array}{l}34,0 \\
34,8\end{array}$ & $\begin{array}{l}42,1 \\
39,4\end{array}$ & $\begin{array}{l}24,4 \\
28,4\end{array}$ & $\begin{array}{l}32,9 \\
29,7\end{array}$ \\
\hline $\begin{array}{l}\text { 4. People other than } \\
\text { health personnel } \\
\text { only }\end{array}$ & $\begin{array}{l}\text { Male } \\
\text { Female }\end{array}$ & $\begin{array}{l}1,1 \\
1,0\end{array}$ & $\begin{array}{l}1,0 \\
3,2\end{array}$ & 4,5 & $\begin{array}{l}2,1 \\
2,1\end{array}$ & $\begin{array}{l}3,3 \\
2,1\end{array}$ & $\begin{array}{l}1,1 \\
2,3\end{array}$ \\
\hline $\begin{array}{l}\text { 5. Mass media and } \\
\text { people other than } \\
\text { health personnel }\end{array}$ & $\begin{array}{l}\text { Male } \\
\text { Female }\end{array}$ & $\begin{array}{l}34,0 \\
31,1\end{array}$ & $\begin{array}{l}21,9 \\
12,8\end{array}$ & $\begin{array}{l}20,4 \\
19,6\end{array}$ & $\begin{array}{r}12,6 \\
9,6\end{array}$ & $\begin{array}{r}14,4 \\
8,4\end{array}$ & $\begin{array}{l}24,8 \\
20,3\end{array}$ \\
\hline $\begin{array}{l}\text { 6. Health personnel } \\
\text { and people other } \\
\text { than health per- } \\
\text { sonnel }\end{array}$ & $\begin{array}{l}\text { Male } \\
\text { Female }\end{array}$ & 2,1 & - & $\overline{0}, 9$ & $\begin{array}{l}2,1 \\
1,1\end{array}$ & $\begin{array}{l}1,1 \\
-\end{array}$ & $\begin{array}{l}1,2 \\
0,3\end{array}$ \\
\hline $\begin{array}{l}\text { 7. Health personnel } \\
\text { and mass media }\end{array}$ & $\begin{array}{l}\text { Male } \\
\text { Female }\end{array}$ & $\begin{array}{l}4,3 \\
5,8\end{array}$ & $\begin{array}{r}9,4 \\
13,8\end{array}$ & $\begin{array}{l}10,7 \\
15,2\end{array}$ & $\begin{array}{l}12,6 \\
20,2\end{array}$ & $\begin{array}{l}30,0 \\
26,3\end{array}$ & $\begin{array}{r}9,3 \\
12,6\end{array}$ \\
\hline $\begin{array}{l}\text { 8. Health personnel, } \\
\text { mass media and } \\
\text { people other than } \\
\text { health personnel }\end{array}$ & $\begin{array}{l}\text { Male } \\
\text { Female }\end{array}$ & $\begin{array}{l}17,0 \\
21,4\end{array}$ & $\begin{array}{l}15,6 \\
14,9\end{array}$ & $\begin{array}{r}18,5 \\
8,9\end{array}$ & $\begin{array}{l}13,7 \\
16,0\end{array}$ & $\begin{array}{l}12,2 \\
15,8\end{array}$ & $\begin{array}{l}16,2 \\
16,6\end{array}$ \\
\hline TOTAL & $\begin{array}{l}\text { Male } \\
\text { Female }\end{array}$ & $\begin{array}{l}100,0 \\
100,1\end{array}$ & $\begin{array}{r}99,9 \\
100,1\end{array}$ & $\begin{array}{l}100,1 \\
100,0\end{array}$ & $\begin{array}{r}99,9 \\
100,1\end{array}$ & $\begin{array}{r}99,8 \\
100,0\end{array}$ & $\begin{array}{l}100,1 \\
100,0\end{array}$ \\
\hline $\begin{array}{l}\text { Since a stratified } \\
5 \% \text { subsample of the }\end{array}$ & $\begin{array}{l}\text { mple was us } \\
80 \text { census. }\end{array}$ & centa & for ea & gro & e sta & d se & ely against the \\
\hline
\end{tabular}

Doctors and nurses as sources of information featured in the fifth place (males $22 \%$, females $24 \%$ ) with more than one-third of the respondents of both sexes in the oldest age group (55 to 64 years) mentioning this source, whereas respondents in the youngest age groups mentioned it to a lesser extent. Only $14 \%$ of the males and $18 \%$ of the females learnt about preventing heart disease at day hospitals or clinics. In the youngest age group $42 \%$ of the males and $38 \%$ of the females stated that they had received information from teachers. These percentages were much lower for the older age groups. Their place of work as a source of information was mentioned by only $16 \%$ of the males and $11 \%$ of the females. The least mentioned source was schoolchildren conveying information at home.

According to their answers to this question, respondents were further subdivided into eight categories (Table 3 ).

It appears that

- $14 \%$ of the males and $17 \%$ of the females received no information at all (1) on the prevention of CHD

- mass media as the only source of information (3) was mentioned by approximately one-third of both males and females.

- mass media as the only source (3), combined with people other than health personnel (5) (in other words without any information from health personnel), was mentioned by $58 \%$ of males and $50 \%$ of females.

- health personnel as the only source (2), combined with people other than health personnel and/or mass media $(6,7$ and 8 ) was mentioned by $28 \%$ of the males and $31 \%$ of the females - i.e. less than a third of each sex group received information from health personnel.

- the three types of sources - mass media, health personnel and people other than health personnel combined (8) was mentioned by only $16 \%$ of the males and $17 \%$ of the females.

\section{Media Preferences}

The respondents were also asked to select the three media which they considered to be the most effective for conveying information to their community on the prevention of heart disease from a list and to place them in order of priority. The results are shown in Table 4 . Television was chosen most often: $78 \%$ of the males and $79 \%$ of the females listed it as first, second or third choice - similar percentages occurred in each age and sex category. This was followed by instruction given to schoolchildren (males 55\%; females 50\%). Again the trends were similar for each age and sex group. Newspapers (males $31 \%$; females $36 \%$ ) featured in the third place, lectures (males $30 \%$; females $29 \%$ ) in the fourth and day hospitals/clinics in the fifth (males 19\%; females $26 \%$ ). The two least preferred media were pamphlets and magazines.

When the respondents' first choices only were considered, the first five sources of 


\section{TABLE 4}

Preferred sources of information (first, second and third choices jointly) according to sex and age Source of infor-

mation

$\begin{array}{ll}\text { Television } & \text { Respondents } \\ & \text { Male } \\ \text { Instruction to } & \text { Memale } \\ \text { school children } & \text { Female } \\ \text { Newspapers } & \text { Male } \\ & \text { Female } \\ \text { Lectures } & \text { Male } \\ & \text { Female } \\ \text { Posters } & \text { Male } \\ & \text { Female } \\ \text { Day hospital/ } & \text { Male } \\ \text { Clinic } & \text { Female } \\ \text { Radio } & \text { Male } \\ & \text { Female } \\ \text { At work } & \text { Male } \\ & \text { Female } \\ \text { Magazines } & \text { Male } \\ & \text { Female } \\ \text { Pamphlets } & \text { Male } \\ & \text { Female }\end{array}$

* Since a stratified sample was used percentages for each sex group were standardised separately against the

5\% subsample of the 1980 census.
$\%$ of participants in each age group

$15-24$
73,4
75,7
61,7
52,4
30,9
36,9
33,0
33,0
21,3
24,3
18,1
24,3
16,0
15,5
22,3
10,7
8,5
17,5
14,9
9,7

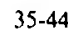

82,5

82.1

42,7

53,6

31,1

36,6

33,0

28.6

24,3

19.6

19.4

27,7

17,5

17,0

17,5

14,3

13,6

17,0

18,5

3,6

\section{5-54}

74,7

81,9

53,7

55,3

37,9

39,4

27,4

23.4

24,2

14,9

16,8

28,7

22, 1

21,3

25,3

8,5

10,5

13,8

7,4

12,8
Age standard-

ised rate*

15-64

77,5

78,7

55,1

50,3

31,1

36,3

30,1

28,6

22,2

21,9

18,9

26,4

17,9

18,7

22,0

11,6

11,4

16,5

13,7 information in order of preference were television, instruction at school, lectures, posters and day hospitals/clinics (table not reported). Newspapers as a source was a very popular third choice.

\section{DISCUSSION}

In view of the disease pattern related to CHD, the apparently increasing CHD mortality rate and the poor coronary risk factor profile of the coloured population, the need for a CHD intervention programme for this population group is evident. In the development of such a programme the important role of media use and preference should not be overlooked.

\section{No Information Received}

With reference to the seriousness of the CHD problem among the coloured population, the finding of this study that $14 \%$ of the males and $17 \%$ of the females had received no information on $C H D$ prevention at all is disconcerting. Effective ways will have to be found to reach every member of the population. In this study a number of possibilities that need exploring came to light.

\section{Television}

The most outstanding aspect of the findings is that television was not only the medium mentioned most frequently as a source of information on the prevention of heart disease by all the age and sex groups, but that it was also the most preferred source, both as first choice and overall as one of three most effective ways of reaching the community. This suggests that more use can be made of television in a health communication programme. The interest in this audiovisual medium also suggests that video programmes can be shown to good effect in clinic/day hospital waiting rooms. In this setting the electronic media should ideally be used in combination with interpersonal communication between viewers and health personnel in order to ensure that information is correctly understood and questions answered. Interpersonal communication could for instance take the form of small group discussions.

\section{Radio}

The radio, although mentioned as a source of information by approximately $40 \%$ of the respondents, was listed as one of three most preferred sources of information by less than $20 \%$ of the respondents. This finding should be considered together with the greater preference for televisior. It should be borne in mind that the population in this study was an urban one and therefore had greater access to television sets than would a rural population. In the rural areas the radio may well be a more popular source of information. In the hospital or clinic setting tape cassettes can, as in the case of video programmes, be a useful aid to health guidance if used in conjunction with interpersonal communication.

\section{Printed Material}

Another important finding is that printed material (magazines, pamphlets, books, newspapers) was the second most important source of information concerning CHD prevention. However, when preferred sources are considered, it seems that newspapers were popular (both as third choice and overall as one of three most preferred ways of guidance) whereas pamphlets and magazines were at the bottom of the list. This finding may be due to a greater exposure to newspapers than to pamphlets and magazines and would suggest that more attention should be paid to using newspapers more extensively for conveying information on the prevention of $\mathrm{CHD}$. Concerning the relative unpopularity of pamphlets, it should be borne in mind that pamphlets are often designed for nationwide and cross-cultural use and thus may not attract or hold the attention of all readers. It is suggested that any information material such as pamphlets, posters and videos should not only be designed for a specific target group but that it should be developed in cooperation with members of the group to ensure that it ties up with the language and idiom, perceptions and needs of the group.

\section{The School}

The school as a preferred source of information was mentioned second most frequently both as a first preference and overall as one of three most effective sources of guidance on CHD prevention. However teachers as an actual source was mentioned by less than one-quarter of the respondents. These findings suggest that the school can be used more effectively to teach CHD prevention. It also seems that the school years are an ideal time for health education as lifestyle, which is an all-important factor affecting the incidence of CHD, is learnt in childhood and is very difficult to change in later years. Ideally trained health educators should be used for the health programmes in schools.

\section{Place of Employment}

As far as their place of work was concerned, it is interesting to note that only $16 \%$ of the males and $11 \%$ of the females mentioned it as a source of information on CHD prevention. As a preferred source it was mentioned as one of three most effective sources by $22 \%$ of the males and $12 \%$ of the females. The place of work was not perceived as an effective source by the majority of the respondents. However if it is taken into account that a large part of a person's time is spent at work and that his experiences at work greatly influences his lifestyle, the possibilities of education at work should be seriously considered in any CHD intervention programme. Trained health educators with appropriate aids should be available to visit workplaces to give talks to the workforce.

\section{Health Personnel}

A desire for interpersonal communication was expressed by almost one-third of the respondents who suggested lectures as one of the three most effective ways of teaching the community about CHD prevention. A preference for receiving information from day hospitals/clinics was also listed by $19 \%$ of the males and $26 \%$ of the females. Less than half the respondents reported that they had received information on 
CHD from health personnel. Nursing staff could contribute to effective health guidance but the real need is for appropriately trained health educators. They could for instance assist by leading group discussions after the viewing of television programmes and by treating every contact with patients as an opportunity for health education. Health education should become an important aspect of any health service and should be greatly expanded.

\section{Mass Media and Interpersonal}

\section{Communication}

The findings of other studies (McAllister 1980; Steyn M. et al. 1981a, 198 Ib, 1987) have shown that although health education that is provided through the mass media alone does have some effect, programmes combining mass media and interpersonal communication are more successful in changing behaviour. It is therefore suggested that in planning any $\mathrm{CHD}$ intervention programme the very

important role of health personnel as far as erpersonal guidance is concerned should not be overlooked. This is particularly important since the use of mass media seems to be effective especially in the area of creating an awareness of a situation whereas interpersonal guidance seems to be more effective when people have to be persuaded to adopt new ideas (Rogers 1983: 18; Bettinghaus 1980: 160). Although both types of media can be used to advantage in health education it should be borne in mind that the mass media can be used to reach a great number of people whereas interpersonal communication reaches fewer people but provides an opportunity for immediate feedback and therefore for clearing up any misunderstanding. Furthermore, as was illustrated by the findings of this study, many people are reached by the mass media or by interpersonal communication but not necessarily by both types of communication.

\section{CONCLUSION}

A multi-media approach is advocated for any intervention programme. In this way various communication media (interpersonal communication included) can be used in combination. Successful communication is not based on the use of one medium alone but on a multi-media approach in which various media complement each other. Such an approach has the advantage that the range and impact of a programme is greatly enhanced.

\section{REFERENCES}

Bettinghaus, E.P. 1980. Persuasive communication (3rded.) New York: Holt, Rinehart and Winston.

McAlister, A. et al. 1980. Psycology in action: mass communication and community organisation for public health education. American Psychologist, 35 (4): 375-379.

Rogers, E.M. 1983. Diffusion of innovations (3rd ed.) New York: The Free Press.

Steyn, K. et al. 1985. Coronary risk factors in the coloured population of the Cape Peninsula. South African Medical Journal, 67: 619-625.

Steyn, K. et al. 1986. Hypertension in the coloured population of the Cape Peninsula. South African Medical Journal, 69: 165-169.

Steyn, K. et al. 1987a. Smoking patterns in the coloured population of the Cape Peninsula,
(CRISIC STUDY). South African Medical Journal, 71: 145-148.

Steyn, K. et al. 1987b. Hypercholesterolaemia in the coloured population of the Cape Peninsula, (CR ISIC STUDY). South African Medical Journal, 71: 483-486.

Steyn, M. et al. 1981a. Koronêre risikofaktorstudie: Trefwydte en inslag van die hen'usmakingsprogram. Pretoria: Human Sciences Research Council.

Steyn, K. et al. 1989a. Factors associated with high density lipoprotein cholesterol in a population with high HDL-cholesterol levels The CRISIC study. Arteriosclerosis. (in press).

Steyn, K., Joubert G., Rossouw J.E. The coexistence of the major risk factors for coronary heart disease in the coloured population of the Cape Peninsula. The CRISIC study. South African Medical Jotrnal (1989b accepted for publication).

Steyn, M. et al. 1981b. Koronêre risikofaktorstudie: Trefwydte en inslag van die oorredingsprogram. Pretoria: Human Sciences Research Council.

Steyn, M. et al. 1987. 'n Ondersoek na die kennis, houdings en gebruike van 'n groep blanke moeders rakende borsvoeding en kindervoeding. Pretoria: Human Sciences Research Council.

Acknowledgements

The authors wish to acknowledge the contributions of

1. the staff of the regional office, Cape Town; the Institute for Communication Research; the Institute for Statistical Research, and the Bureau for Support Services of the Human Sciences Research Council,

2. the staff of the Research Institute for Nutritional Diseases of the SA Medical Research Council,

3. nurses of the Department of Health and Welfare. 